$\xi_{p}=-$ 圆

\title{
Role of information and communication technology in empowerment of women in Tamil Nadu
}

\author{
V. Janaki * \\ Part-Time Research Scholar, Vels Institute of Science, Technology and Advanced Studies (VISTAS), Chennai \\ *Corresponding author E-mail: janakirajan1995@gmail.com
}

\begin{abstract}
This study examines the impact of information and communication technology (ICT) on empowerment of women in Tamil Nadu. Information and communication technology has brought sweeping changes in the life of women. It has helped to break the shackles of slavery and facilitated greater empowerment of women. The present study has revealed that women using tablets, personal computers, internet con-nectivity, SMS, E-mail, Whats App, Facebook and internet browsing are more empowered socially, psychologically and intellectually than others. It is also found that use of ICT has increased the sense of self-worth and led to more social activism by women. It has also empow-ered women to make their own decisions on important aspects of their personal life such as education, employment, marriage, child birth etc. ICT has facilitated networking which make them aware of the job opportunities worldwide. ICT has increased the awareness about the law of the land which helps them to protect against injustice, discriminations and violence. ICT has integrated women with the society which has led to greater confidence and security.
\end{abstract}

Keywords: Empowerment Index; Information and Communication Technology; Intellectual Empowerment; Psychological Empowerment; Social Empowerment; Women Empowerment.

\section{Introduction}

Information and communication technology (ICT) is an umbrella term which encompasses a wide spectrum of technologies like telecommunications, audiovisuals, net-working, data processing, software programming, e-mails, digital television, mobile phones, computers, laptops and communication robots (Bimber 1998). ICT has revolutionized the world. It has removed the physical barriers between nations and transformed them into a monolithic unit. It has shortened the distance and brought the continents closer (Zuppo 2012). The impact of social media like Face book and Twitter has brought sweeping changes throughout the world. Social media have brought culturally different people together and created the 'global citizens'. ICT has facilitated accurate and speedy processing of information which has enormously increased the efficiency of people. Applications like word processors, database programs, spread sheets etc. have helped people to run their organizations more efficiently. Information technology has made communication cheaper and quicker. E-mails, video chats, video conferences, text messages have made people come together as never before. ICT has revolutionised entertainments with the help of smart phones and iPods. Wireless communication has brought great changes in news broadcasting (Daintith 2009). Information technology has made businesses easy through online transactions. Banking and money transfers are made much easier now. ICT has revolutionised healthcare through tele-medicines, electronic health records, mobile medical apps and health grids. Information and communication technology has made sweeping changes in the field of education by bidding goodbye to class rooms and conventional teachings. It has created millions of jobs all over the world. It has provided remote accessibility and helped organisations to do business globally. It has increased labour productivity. It provides the employees a lot of leisure by helping them work from home (Murray 2011).

\section{Status of women}

Historically, except during a few episodic periods, women have comparatively occupied a lower social status than men in India have. Her battle for survival begins right from inception and if at all she survives feticide and infanticide, she has to meet a chain of brutal onslaughts by a feudalistic society in her later life. She is a historical victim of sati, purdah and devadasi system. All through her life she is blindfolded and lives in ignorance. Her life is surrounded by superstitions. Her support base is weak and she has to fend for herself (Nubile 2003).

Child marriage and pre-puberty marriage are still practiced widely in India. According to UNICEF's Report 'State of the World's Children-2009', 47\% of Indian women aged 20-24 were married before the legal age of 18 , and it is higher by $56 \%$ in rural areas (UNICEF 2009). The report also showed that $40 \%$ of the world's child marriages occur in India (Dhar 2009). Child marriage leads to child widowhood which is a humiliating experience. Women in India live a subdued life. Their life is mired in socio-economic slavery. All through her three stages of life viz. daughter, wife and mother, a woman encounters insurmountable problems. She is being taught from her childhood to obey and remain subservient and humble. She is supposed to be passive and remain silent even under great provocation. She is a victim of domestic violence and dowry harassment. She has not been given a rightful place in education and healthcare. She perpetually remains poor as the inheritance laws of the land remain only in the papers. Her political importance is insignificant (Parihar 2011). 


\section{Empowerment of women}

One of the Millennium Development Goals of the United Nations vows to promote gender equality and empowerment of women. Ensuring gender equality will have multiplier effect on society. Millennium Development Goals urges member nations to make significant progress towards gender equality in the fields of education, employment, and political representation. Gender based discrimination in the deliverance of justice is another setback in women empowerment. The law enforcing authorities are not well disposed towards women. Discrimination is widespread and women always hesitate to approach the court of law for fear of social stigma. For a very long time, women did not have equal rights over property of her parents as men had. Even now property rights for women remain only in papers (Jayapalan 2001). The participation rate of women in politics is low (Chhibber 2002). Indian women also lack experience in leadership which inhibits their participation in politics. They are also overburdened with household work which reduces their participation in political activities (Mohan 2011).

\section{Communication and women}

Indian women are caged birds. Seclusion from birth to death is part of their life. Communication by women is restricted in every aspect. It is said that a virtuous woman should not communicate with the outside world at all. Even newspaper reading by a woman is considered to be unwomanly and unacceptable. In some homes, even to speak to one's parents, she has to get a clearance from her husband and in-laws. When visitors come home, a woman is not supposed receive them or to speak to them. Every word spoken by a woman is censored by her family members. According to Manusmriti, women are supposed to lower their heads and speak only a fewer words in lower voice. A woman who communicates with others freely is branded as characterless. Such women will have no takers in the marriage market and it is hard to find a groom. Relatives and husbands may find her embarrassing and consider her a shame of the family (Newsgram 2017).

Communication will improve the self-worth and social networking will add to her stature and self-confidence. When women are given a free hand to communicate, they may make economic gains which will enhance her empowerment. Free communication will help them to have access to law enforcing authorities which will ensure their safety and security. When free communication is denied, their knowledge base may shrink and they may be forced to live an inhuman life. Access to communication instruments like telephones is restricted to women fearing that they may be exposed to the outside world. Many families prohibit women from using mobile phones. Women are not permitted to use emails Respectable women in India are not expected to use facilities like face book or any other social media.

\section{Review of literature}

The digital revolution can help women empowerment in a big way. E-commerce suits the flexible timing she requires. Online business can substantially increase her economic status and self-worth. ICT enables women to come to the main stream of social progress. Participation in e-commerce may one day lead to entrepreneurship. E-commerce is a simple way by which women can begin their life. The money earned by e-commerce by women may be usefully spent in health food and education which may have a multiplier effect (Agrawal 2010). Safety of women is a big concern in India. Brutal attacks on women are a daily occurrence. Instances like the gang-rape and murder of 'Nirbhaya' happens to many others too. But mobile phones - an outcome ICT revolution has increased the safety of women by increasing their access to law enforcing authorities. Mobile phones play a major role in the life of women. It has increased their social network and empowerment. ICT revolu- tion has removed the drudgery in the life of women by providing them with entertainments like video games and audio facilities (Shipway 2004). Communication and information technology has opened up new vistas of economic gains for women. It has created millions of jobs in India. It has paved the way for economic independence and security (Emanuel 2015). ICT revolution has increased their accessibility to newspapers. The using of internet has also increased women empowerment (Morahan-Martin 2000).

\section{Research work}

\subsection{Objective}

The main objective of the study is to elucidate the role of information and communication technology (ICT) in the empowerment of women in Tamil Nadu.

\subsection{Hypothesis}

1) Possession of high-end communication devices such as tablet and personal computer improves the level of psychological empowerment among women.

2) Access to social networking applications improves the social empowerment level of women.

3) Internet browsing leads to intellectual empowerment of women.

\subsection{Data - collection, tabulation and analysis}

This research is based on primary data collected through survey method using structured interview. Both printed and electronic questionnaires were used. The data was collected from 640 women born and brought up in Tamil Nadu through stratified random sampling method. The data collected through the survey were entered into the SPSS data sheet directly. The analysis of the data was done using Microsoft Excel and IBM SPSS 20 software. The tools used for the analysis are frequency analysis, cross-tabulation and Chi-Square analysis.

\subsection{Measurement of empowerment}

For the present study, the empowerment level of the respondents are measured through the Social Empowerment Index (SEI), Psychological Empowerment Index (PsyEI), Intellectual Empowerment Index (IEI) and Overall Empowerment Index (EI). These indices are measured in a 10-point scale based on different dimensions with appropriate weightages. An index of 0.00 to 3.00 denotes 'low' level of empowerment; an index of above 3.00 indicates 'high' level of empowerment. The Overall Empowerment Index denotes the total empowerment level including economic empowerment, physical empowerment, domestic empowerment and political empowerment of the respondents apart from the three indices mentioned above.

\subsubsection{Social empowerment index (SEI)}

Social Empowerment Index comprises three dimensions such as Communication, Social Activism and Socio-cultural participation. The indicators for [Dimension 1] Communication are access to communication devices and familiarity with communication techniques; [Dimension 2] Social Activism are visibility outside family and involvement in activities uplifting the society; and [Dimension 3] Socio-cultural participation are the participation in social events, religious events, cultural events, hobby related activities, sports, games etc. and visiting public places such as library and entertainment centres etc.

\subsubsection{Psychological empowerment index (PsyEI)}

Psychological Empowerment Index comprises four dimensions such as Sense of self-worth, Decision-making in personal life, 
Attitude towards violence against women and Coping-up strategy. The indicators used for [Dimension 1] Sense of self-worth are feeling proud about oneself and about being a woman, feeling respected by the family members, and involvement of dowry in marriage; [Dimension 2] Decision-making in personal life are the involvement in decision-making related to one's own education, employment, marriage, child-birth and spending one's own earnings; [Dimension 3] Attitude towards violence against women are one's attitudes related to the victims and the victimization of victims in the untoward incidents of eve-teasing, acid attacks, rape and rape attempts, indecent representation and undignified treatment of women at public places; and [Dimension 4] Coping-up strategy are the stress-management techniques adopted by women during distress.

\subsubsection{Intellectual empowerment index (IEI)}

Intellectual Empowerment Index comprises four dimensions such as Educational status, Vision, Legal awareness and Edutainment. The indicators used for [Dimension 1] Educational Status are level of education and field of graduation; [Dimension 2] Vision are involvement in self-improvement activities and educating girls; [Dimension 3] Legal awareness is the knowledge of various acts and rules related with women empowerment; and [Dimension 4] Edutainment is the manner in which the leisure time is used for enrichment of knowledge.

\subsection{Analysis of data}

\subsubsection{Access to communication devices}

The data obtained from the survey was cross-tabulated in Table 1 to determine the mean of various empowerment indices with respect to the respondents having access to the communication devices and the others. The communication devices taken up for the study are mobile phones, tablets or notepads, personal computersdesktop or laptop and internet connectivity devices.

Table 1: Access to Communication Devices and Empowerment Indices

\begin{tabular}{llllll}
\hline Access available & & SEI & PsyEI & IEI & EI \\
\hline \multirow{2}{*}{ Mobile Phone } & Yes & 3.26 & 6.34 & 4.97 & 4.82 \\
Tab / & No & 1.63 & 5.21 & 3.81 & 3.37 \\
Notepad & Yes & 5.20 & 8.13 & 6.64 & 6.10 \\
Personal Computer & No & 2.92 & 6.06 & 4.69 & 4.58 \\
& Yes & 4.77 & 7.33 & 6.24 & 5.82 \\
Internet & No & 2.35 & 5.74 & 4.22 & 4.19 \\
& Yes & 5.19 & 7.18 & 6.53 & 5.92 \\
& No & 2.30 & 5.89 & 4.20 & 4.23 \\
\hline
\end{tabular}

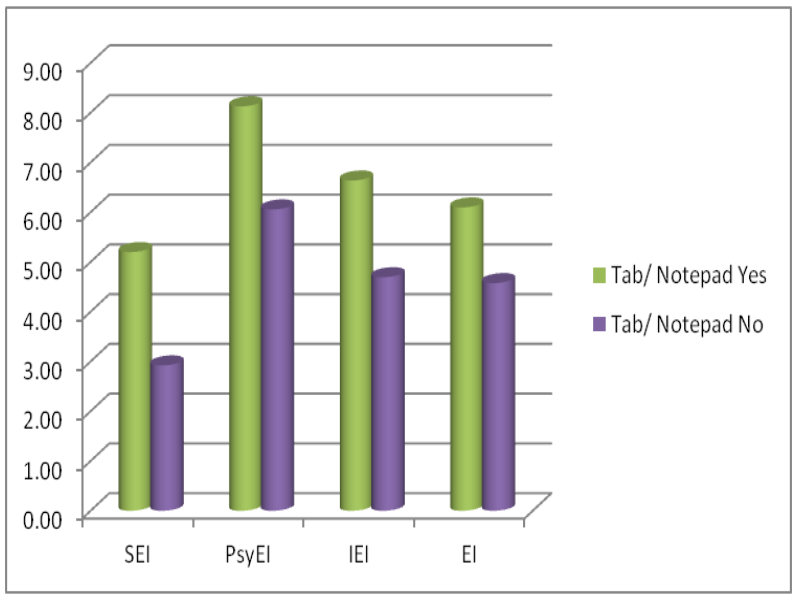

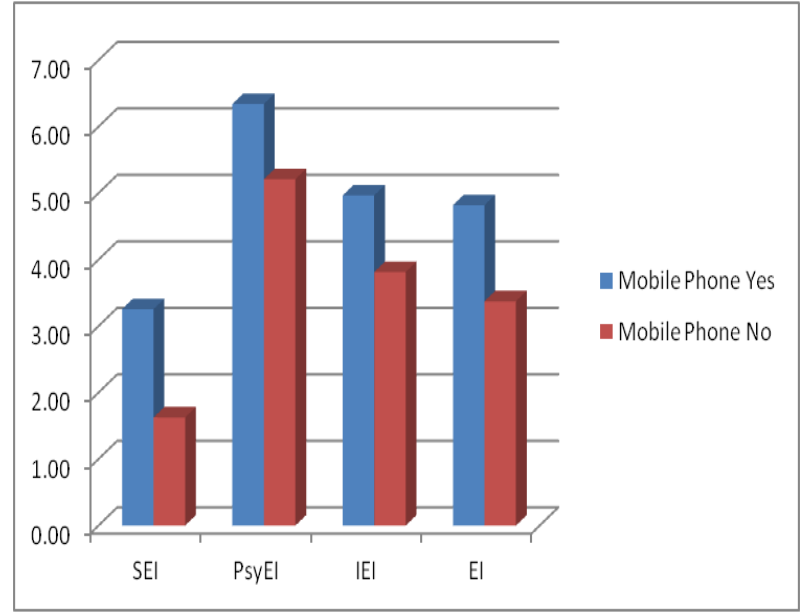
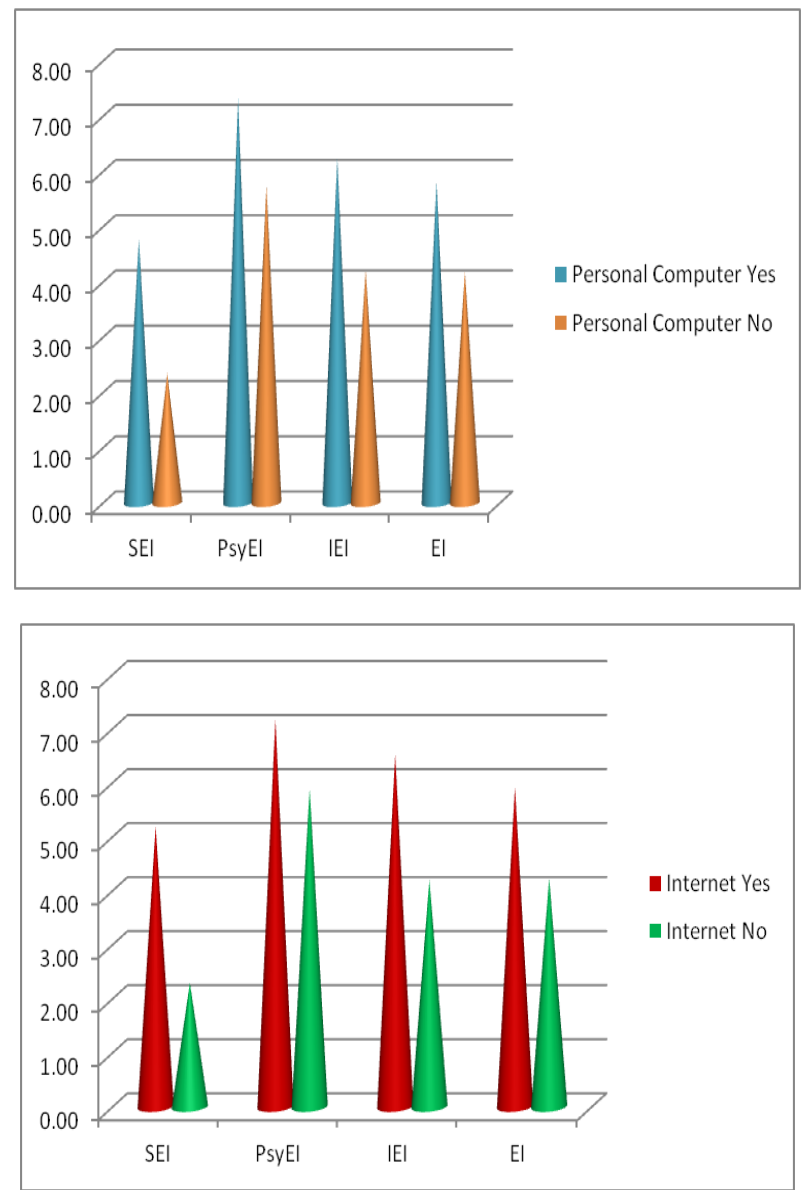

Fig. 1: Impact of Communication Devices on Empowerment of Women.

It is seen from Table 1 and Fig. 1 that the empowerment indices of the respondents not having access to the communication devices are invariably lower than those who possess them. It is apparent that Social Empowerment Index of the respondents is the worst affected by not having access to the communication devices. The Chi-Square analysis was done to determine whether there is any significant association exists between the access to communication devices and the overall empowerment level of the respondents.

Table 2: Level of Empowerment Based on Access to Communication Devices

\begin{tabular}{llllll}
\hline \multirow{2}{*}{$\begin{array}{l}\text { Access to Commu- } \\
\text { nication Device }\end{array}$} & \multicolumn{2}{l}{$\begin{array}{l}\text { Empowerment level } \\
\text { Low } \\
(\mathrm{N}=407)\end{array}$} & $\begin{array}{l}\text { High } \\
(\mathrm{N}=233)\end{array}$ & $\begin{array}{l}\text { Total } \\
(\mathrm{N}=640)\end{array}$ & $\begin{array}{l}\text { Chi- } \\
\text { Square }\end{array}$ \\
\hline \multirow{3}{*}{ Mobile } & Yes & 406 & 232 & 638 & 0.160 \\
& No & 1 & 1 & 2 & $\begin{array}{l}\mathrm{df}=1 \\
\mathrm{p}=0.689\end{array}$ \\
Tablet/ & Yes & 18 & 20 & 38 & 4.594 \\
Notepad & No & 389 & 213 & 602 & $\mathrm{df}=1$ \\
\hline
\end{tabular}




\begin{tabular}{llllll}
\hline & Yes & 72 & 94 & 166 & $\mathrm{p}=0.032$ \\
Laptops/ & No & 335 & 139 & 474 & $\mathrm{df}=1$ \\
Desktops & $\mathrm{p}=0.000$ \\
Internet & Yes & 165 & 129 & 294 & $\begin{array}{l}13.112 \\
\mathrm{df}=1\end{array}$ \\
Connectivity & No & 242 & 104 & 346 & $\mathrm{p}=0.000$ \\
\hline
\end{tabular}

It can be inferred from Table 2 that majority of the mobile phone holders (406) have low level of empowerment and there is no significant association between possession of mobile phones and empowerment as depicted by the insignificant Chi-Square value $(0.160 ; \mathrm{df}=1 ; \mathrm{p}=0.689)$. But, there is a significant association between possession of Tablet/Notepad and Empowerment as the Chi-Square value (4.594; $\mathrm{df}=1 ; \mathrm{p}=0.032)$ is significant. Majority of the Women (602) do not possess tablet/notepad and among them majority of them (389) have low level of empowerment. Similarly, majority of the women (474) do not possess laptops/desktops. But majority of the women with laptops/desktops (94) are highly empowered. There is also a significant association between possession of laptops/desktops and empowerment as inferred by the significant Chi-Square value $(39.582 ; \mathrm{p}=0.000 ; \mathrm{df}=1)$. Similarly, there is significant association between empowerment and possession of internet connection $(13.112 ; \mathrm{df}=1 ; \mathrm{p}=0.000)$ as illustrated by the significant Chi-Square value.

\subsubsection{Modes of communication used}

A study was undertaken to find out the relationship between the various modes of communication used and the level of empowerment of women. The data collected were cross-tabulated in

Table 3 with respect to the usage of SMS, E-mail, Whats App and Facebook and the mean of empowerment indices viz. Social Empowerment Index (SEI), Psychological Empowerment Index (PsyEI), Intellectual Empowerment Index (IEI) and Over-all Empowerment Index (EI) of the respondents.

Table 3: Modes of Communication Used and Empowerment Indices

\begin{tabular}{llllll}
\hline $\begin{array}{l}\text { Mode of } \\
\text { Communication }\end{array}$ & & SEI & PsyEI & IEI & EI \\
\hline \multirow{2}{*}{ SMS } & Yes & 4.23 & 6.75 & 5.98 & 5.41 \\
& No & 2.49 & 5.98 & 4.22 & 4.31 \\
E-Mail & Yes & 5.14 & 7.16 & 6.41 & 5.84 \\
& No & 2.41 & 5.94 & 4.33 & 4.32 \\
\multirow{2}{*}{ Whats App } & Yes & 5.02 & 7.55 & 6.38 & 5.84 \\
& No & 2.37 & 5.73 & 4.27 & 4.27 \\
Facebook & Yes & 5.90 & 7.12 & 6.97 & 6.03 \\
& No & 2.53 & 6.08 & 4.42 & 4.44 \\
\hline
\end{tabular}

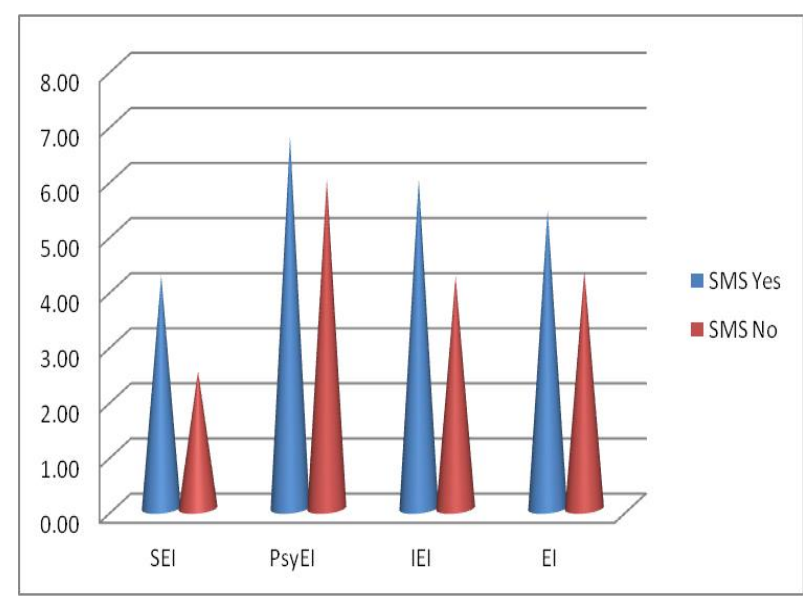

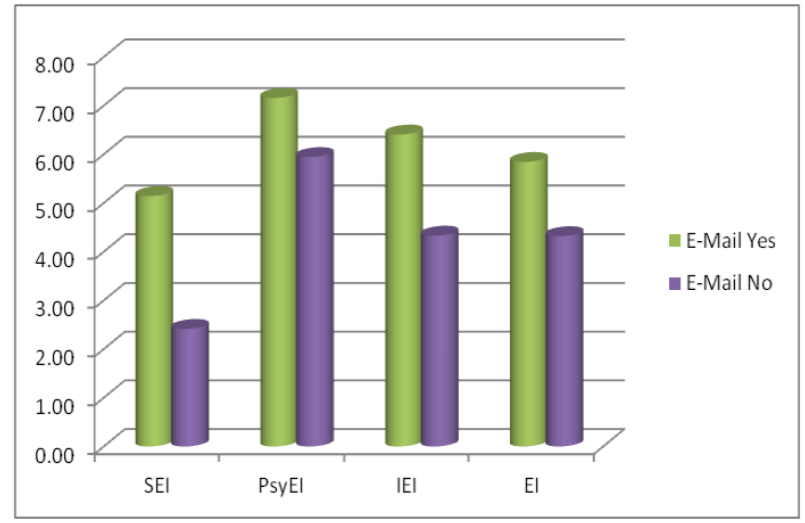
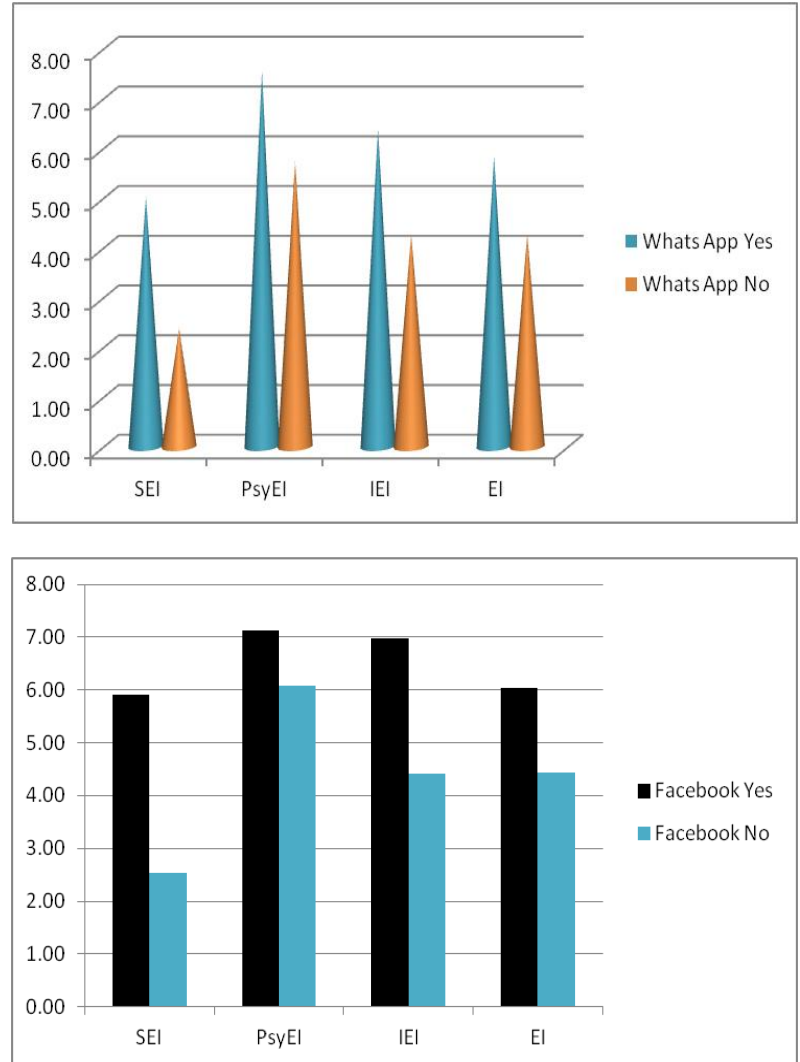

Fig. 2: Impact of Usage of Different Modes of Communication on Empowerment Indices.

\section{It could be seen from}

Table 3 and Figure 2 that the empowerment indices viz. SEI, PsyEI, IEI and EI of the respondents not using the communication modes such as SMS, E-mail, Whats App and Facebook are low compared with those who use these modes. The difference in PsyEI is the least with respect to the usage or non-usage of all the modes studied whereas that of SEI is the highest followed by IEI.

\subsubsection{Time spent on ICT}

The Contribution of Information and communication technology in empowerment was assessed based on the time spent on Information/ Communication devices. The overall empowerment encoded as low and high was cross tabulated with the time spent on Information/Communication technology and its relationship was evaluated using Chi-Square test. The results are tabulated in Table 4. 
Table 4: Level of Empowerment Based on Time Spent on ICT

\begin{tabular}{|c|c|c|c|c|c|}
\hline \multirow{2}{*}{\multicolumn{2}{|c|}{ Use of Information and Communication Technology }} & \multicolumn{3}{|c|}{ Level of Empowerment (EI) } & \multirow{2}{*}{ Chi-Square } \\
\hline & & Low $\mathrm{N}=407$ & High $\mathrm{N}=233$ & Total $\mathrm{N}=640$ & \\
\hline \multirow{4}{*}{ Reading newspaper and magazines } & Atleast 1 Hour & 73 & 65 & 138 & \multirow{4}{*}{$12.839 \mathrm{df}=3 \mathrm{p}=0.005$} \\
\hline & $30 \mathrm{mts}-1$ Hour & 106 & 53 & 159 & \\
\hline & Less than $30 \mathrm{mts}$ & 124 & 76 & 200 & \\
\hline & Don't do & 104 & 39 & 143 & \\
\hline \multirow{3}{*}{ Watching television and video } & Atleast 1 Hour & 101 & 72 & 173 & \multirow{3}{*}{$10.933 \mathrm{df}=3 \mathrm{p}=0.012$} \\
\hline & 30mts-1 Hour & 100 & 72 & 172 & \\
\hline & Less than $30 \mathrm{mts}$ & 106 & 38 & 144 & \\
\hline \multirow{4}{*}{ Listening to music/ radio } & Atleast 1 Hour & 104 & 71 & 175 & \multirow{4}{*}{$6.211 \mathrm{df}=3 \mathrm{p}=0.102$} \\
\hline & $30 \mathrm{mts}-1$ Hour & 105 & 61 & 166 & \\
\hline & Less than $30 \mathrm{mts}$ & 93 & 60 & 153 & \\
\hline & Don't do & 105 & 41 & 146 & \\
\hline \multirow{4}{*}{ Browsing the internet } & Atleast 1 Hour & 82 & 61 & 143 & \multirow{4}{*}{$13.848 \mathrm{df}=3 \mathrm{p}=0.003$} \\
\hline & $30 \mathrm{mts}-1$ Hour & 78 & 63 & 141 & \\
\hline & Less than $30 \mathrm{mts}$ & 101 & 54 & 155 & \\
\hline & Don't do & 146 & 55 & 201 & \\
\hline \multirow{3}{*}{ Other reading } & $30 \mathrm{mts}-1$ Hour & 94 & 69 & 163 & \multirow{3}{*}{$10.377 \mathrm{df}=3 \mathrm{p}=0.016$} \\
\hline & Less than $30 \mathrm{mts}$ & 104 & 62 & 166 & \\
\hline & Don't do & 120 & 43 & 163 & \\
\hline \multirow{4}{*}{ Other Mass media } & Atleast 1 Hour & 26 & 15 & 41 & \multirow{4}{*}{$5.299 \mathrm{df}=3 \mathrm{p}=0.151$} \\
\hline & $30 \mathrm{mts}-1$ Hour & 98 & 51 & 149 & \\
\hline & Less than $30 \mathrm{mts}$ & 37 & 35 & 72 & \\
\hline & Don't do & 246 & 132 & 378 & \\
\hline
\end{tabular}

It can be inferred from Table 4 that there is a significant association between empowerment and reading newspapers/magazines $\left(\chi^{2}=12.839 ; \mathrm{df}=3 ; \mathrm{p}=0.005\right)$, watching television $\left(\chi^{2}=10.933 ;\right.$ $\mathrm{df}=3 ; \mathrm{p}=0.012)$, browsing the internet $\left(\chi^{2}=13.848 ; \mathrm{df}=3\right.$; $\mathrm{p}=0.003)$, and reading other materials $\left(\chi^{2}=10.377 ; \mathrm{df}=3\right.$; $\mathrm{p}=0.016)$. But there is no significant association between empowerment and Listening to music/radio $\left(\chi^{2}=6.211 ; \mathrm{df}=3 ; \mathrm{p}=0.102\right)$, and using other mass media $\left(\chi^{2}=5.299 ; \mathrm{df}=3 ; \mathrm{p}=0.151\right)$, as depicted by insignificant Chi-Square value.

\section{Conclusion}

Information and communication technology has brought a seachange in the world. It has accelerated speed and helped humanity to conquer time and distance. No other technology since industrial revolution has made such sweeping changes in the world as information and communication technology. ICT has broken human drudgery and provided mankind with more leisure and comforts. Throughout history, Indian women have received a raw deal from the society and they have lived a life of servitude. However, information and communication technology has acted as a catalyst for their freedom and dignity. It has facilitated economic progresses and paved the way for global prosperity. Information and communication has revolutionised the life of women in Tamil Nadu. ICT has enabled women to express themselves. It has provided a platform to ventilate their grievances more boldly than never before. This study has revealed that e-mails, televisions, newspapers etc have led to social, intellectual and psychological empowerment of women. Information and communication technology has increased their self-worth and dignity in the society. It has helped women to protect themselves from all sorts of atrocities like domestic violence and economic deprivation against them.

\section{References}

[1] Agrawal, B. (2010). Gender and Green Governance: The Political Economy of Women's Presence Within and Beyond Community Forestry. New York: Oxford University Press.

[2] Bimber, B. (1998, January 01). The Internet and Political Transformation: Populism, Community, and Accelerated Pluralism. Polity. 31 (1): 133-160, 31(1), pp. 133-160.
[3] Chhibber, P. (2002). Why are Some Women Politically Active? The Household, Public Space, and Political Participation in India. International Journal of Comparative Sociology, 43.

[4] Daintith, J. (Ed.). (2009). IT. A Dictionary of Physics. USA: Oxford University Press.

[5] Dhar, A. (2009, January 18). 40 p.c. child marriages in India: UNICEF. The Hindu.

[6] Emanuel, R. (2015). The Truth about Smartphone Addiction. College student journal, 49(2), 291-299. Retrieved from https://www.researchgate.net/publication/281243425_The_truth_ab out_smartphone_addiction

[7] Jayapalan, N. (2001). Status of women in Hindu society. (J. N, Ed.) New Delhi: Indian society and social institutions.

[8] Mohan, S. (2011). Women's and Political Participation in India Baseline Report. Prepared by NIAS and coordinated by IWRAW Asia Pacific.

[9] Morahan-Martin, J. (2000). Women and the Internet: Promise and Perils. Cyber Psychology \& Behavior, 3(5), 683-691.

[10] Murray, J. (2011, December 18). Cloud network architecture and ICT. Modern Network Architecture. Retrieved March 2018, from http://itknowledgeexchange.techtarget.com/modern-networkarchitecture/cloud-network-architecture-and-ict/

[11] Newsgram. (2017, August 6). New Delhi.

[12] Nubile, C. (2003). The Danger of Gender: Caste Class and Gender in Contemporary Indian Women's Writing. Sarup \& Sons Publishers.

[13] Parihar, L. D. (2011). Women and law: from impoverishment to empowerment. Lucknow: Eastern Book Company.

[14] Shipway, L. (2004). Domestic violence - a healthcare issue. In L. Shipway, Domestic violence: a handbook for health professionals, London (p. 3). New York: Routledge.

[15] UNICEF. (2009). The state of the world's children 2009: Maternal and new born health. UNICEF.

[16] Zuppo, C. M. (2012, August). Defining ICT in a Boundaryless World: The Development of a Working Hierarchy. International Journal of Managing Information Technology, 4(3), 13-22. 